\title{
A Comprehensive Study of Application of Decision Support System in Agriculture in Indian Context
}

\author{
Vidya Kumbhar \\ Symbiosis Institute of Computer Studies \&Research, \\ Pune, India-411016.
}

\author{
T.P.Singh \\ Symbiosis Institute of Geo-Informatics, \\ Pune, India-411016
}

\begin{abstract}
Agriculture is the mainstay in Indian Economy and only sustainable agriculture is likely to provide the long-term benefits required to achieve development and scarcity improvement. The research and advancements in agriculture have made available huge amounts of data in different areas of agriculture. It is a great challenge to extract knowledge from data and this has led to methods and techniques such as decision support system that can bridge the knowledge gap. The effectiveness of decision making in agriculture domain can be improved by integrating geospatial information and advanced information technology techniques. This paper reviews and summarizes the application of simulation based decision support system, advisory decision support system in different agriculture practices in Indian context.
\end{abstract}

\section{KEYWORDS}

Decision Support System, GIS, Simulation, Agriculture, India.

\section{INTRODUCTION}

Agriculture and its allied sectors are the principal sources of livelihood for more than $58 \%$ of the population in India. It plays a significant role in the overall socioeconomic development of India. As per the Advance Estimates (AE) of the Central Statistical Organization (CSO) for the year 201011, the agricultural sector has contributed about 14.2 percent to the GDP, at 2004-05 prices. As per International Trade Statistics 2010, published by World Trade Organization (WTO), India's agricultural exports in 2009 amounted to Rs. 94520 Crore (US \$ 17 billion) with a share of $1.4 \%$ of world trade in agriculture [1]. The total output from the agriculture and allied sectors has increased from $20 \%$ in Triennium Ending (T.E.) $1990-91$ to $25 \%$ in T.E. $2009-10$ at $2004-05$ prices. Currently food grain production constitutes about one fifth of the total value of output from the agriculture \& allied sector which is less than the contribution of the livestock sector and almost equal to that of the horticulture sector [1]. The Indian farmer's $73.33 \%$ households rely only on income from agriculture and $26.66 \%$ farmers get income from other sources like dairy, business, labor and livestock. $76.66 \%$ of farmers selling crops in nearby market and $23.33 \%$ of farmers are selling their crops in their own village or to private money lenders [2]. The statistical substantiation illustrates that sustainability of agriculture will provide long term benefits to achieve the development and scarcity improvement. The paper presents the comprehensive study of the use of decision support system in sustainable agriculture in Indian context.
Table 1 India's share in World Agriculture

\begin{tabular}{|l|l|}
\hline Description & Rank \\
\hline Total Area & Seventh \\
\hline Irrigated Area & First \\
\hline Population & Second \\
\hline Economically Active Population & Second \\
\hline Total Cereals & Third \\
\hline Wheat & Second \\
\hline Rice & Second \\
\hline Coarse Grains & Fourth \\
\hline Total Pulses & First \\
\hline Oil Seeds & Second \\
\hline Fruits and Vegetables & Second \\
\hline Milk & First \\
\hline Live Stock & First \\
\hline \multicolumn{2}{|c|}{ Source: Agriculture Informatics Division, National Informatics } \\
\hline
\end{tabular}

\section{NEED FOR DECISION SUPPORT IN AGRICULTURE}

Sustainable Agriculture production and processing systems have become more complex with involvement of biological, chemical, physical processes such as soil, water, climatic scenarios and crop management practices respectively [3] [4]. Decision Support System (DSS) offers a framework within which complex systems can be represented in a structured way, allowing them to be more easily understood and helping to draw out additional information and new insights [5]. It is an interactive computer based expert system that helps decision makers to utilize data and models to solve unstructured problems [3]. The applicable use of successful decision support can assist in the sustainability of agricultural resources. Based on the important parameters in agriculture such as type of soil, seed, irrigation, fertilizers, and climatic data the activities in agriculture management can be classified into different categories (Figure 1). For effective and sustainable agriculture management decision support system at each of these activities is very much essential.

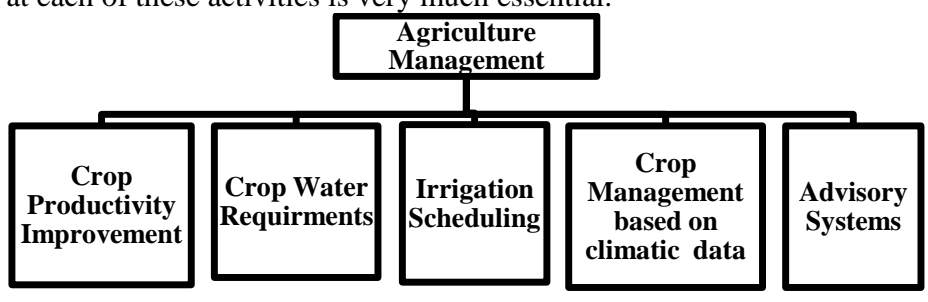

Figure 1 Activities involved in Agriculture Management 


\section{DSS IN AGRICULTURE}

Simulation based DSS models are widely applied in agriculture, as these models provide viable input to the management decisions because of their effective predictive capability. The first simulation based DSS comprising of soil module, weather module and crop module called as a Decision Support System for Agro-technological Transfer (DSSAT) is developed in different regions and crops to decide the type of seed to grow, when and how much to irrigate, rate of application of fertilizer and crop yield prediction [6] [7]. The DSSAT was then modified depending upon the type of crop and agriculture environment (Figure 2).

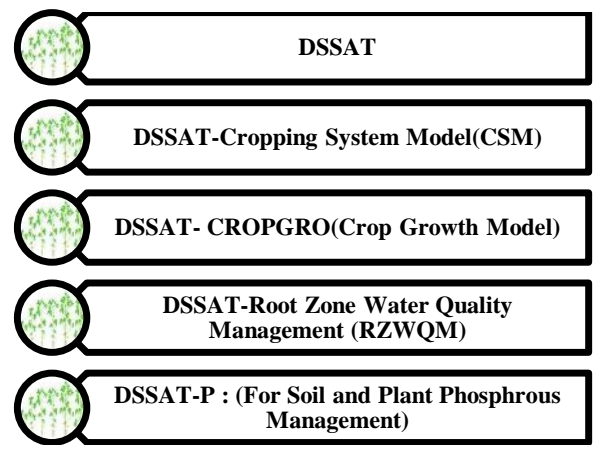

Figure 2 Types of DSSAT

The conventional DSSAT model considered crop predictions on the basis of only soil and plant Nitrogen (N) contents. Along with nitrogen, phosphorus $(\mathrm{P})$ is a major nutrient required in plant growth and reproduction. Land degradation has caused soil P-deficiency which results in a decrease in crop productivity and land cover, increased vulnerability to soil erosion. To resolve this DSSAT was redesigned with soil and plant phosphorus model which is called as DSSAT-P model which helped in simulation of crop growth in Pdeficient environments [8].

DSSAT was also extended to simulate crop yield, nearsurface soil water contents, and cumulative nitrate-N losses associated with regular free tile drainage (TD) and controlled tile drainage with optional subsurface irrigation (CDS). This model has given considerably better results to increase crop yield in uneven rainfall areas [9].

Crop specific DSSAT was combined with Root Zone Water quality model (RZWQM), which simulated detailed yield components, leaf numbers, and phenological development for specific crops. The results of the simulations showed that once a plant growth module is calibrated for a site it could give reasonable results for that climate and soil conditions and they are less affected by soil water and nutrient status. [10].

In addition to DSSAT other different DSS were also developed and applied in different areas of agriculture (Table 2).

Table 2 Different DSS Models in Agriculture Management

\begin{tabular}{|l|l|l|}
\hline $\begin{array}{l}\text { Sr. } \\
\text { No }\end{array}$ & $\begin{array}{l}\text { Name of } \\
\text { DSSAT }\end{array}$ & Application \\
\hline 1. & CROPWAT & DSS tool for land and water management \\
\hline 2. & SWASALT & $\begin{array}{l}\text { DSS tool for Soil and Water Resource } \\
\text { Management }\end{array}$ \\
\hline 3. & CROPMAN & $\begin{array}{l}\text { DSS tool Crop Production and } \\
\text { Management }\end{array}$ \\
\hline 4. & DSS-ET & $\begin{array}{l}\text { DSS tool for soil evapo-transpiration } \\
\text { estimation }\end{array}$ \\
\hline 5. & DSS-FS & $\begin{array}{l}\text { DSS tool with Fertigation Simulator for } \\
\text { application of fertilizers }\end{array}$ \\
\hline 6. & IPM & \begin{tabular}{l} 
DSS for Integrated Pest Management \\
\hline
\end{tabular} \\
\hline
\end{tabular}

\section{DSS IN AGRICULTURE IN AN INDIAN CONTEXT}

\subsection{DSS in crop productivity improvement}

DSS is widely applied in various parts of India for different agricultural management activities. Crop productivity being one such activity, it has given considerably good results with the use of DSS. The DSS named as "Crop Environment Resource Synthesis (CERES) -Wheat", is a part of DSSAT which was successfully applied to simulate the crop growth and development of wheat under variable climatic, water and nitrogen levels in semi-arid and subtropical regions of Punjab for five cropping seasons from 2000-2001 through 20042005(Table 3) [11]. The model results concluded that grain yield and water productivity are affected by water holding capacity of the soils. This model was then extended with Cropping System Model (CSM) named as "DSSAT-CSMCERES-Wheat 4.0". It was calibrated and validated on 13 different datasets of different farms of Ludhiana and Phillaur, Punjab collected between 2002-2006 to predict and increase crop yield and for irrigation scheduling. The model helped for estimating crop yield, evapotranspiration, crop water productivity (CWP) and Irrigation Water Productivity (IWP) (Table 3) [12].

Cropping System Simulation Model (CropSyst) is another simulation based DSS model linked with Geographical Information System (GIS). It uses the identical approach to simulate the growth and development of all herbaceous crops using periodic biomass and Leaf Area Index (LAI). It helped to decide water saving and water productivity policy for rice crop in Punjab by integrating crop management practices such as transplanting date, type of seed and irrigation (Table 3) [13]. Indian Agriculture Research Institute (IARI) then evaluated CropSyst and CERES models, and results of evaluation demonstrated that these models can be effectively applied for on farm management activities such as irrigation and soil nitrogen management [14].

The CROPGRO - Soybean model is a part of DSSAT, which was used to successfully simulate climatic change, growth and yield of soybean for four major states as Madhya Pradesh, Maharashtra, Rajasthan and Karnataka which together contribute $98 \%$ of soybean area in India [15] [16] [17]. It was also used to estimate the potential yields in water limiting and water non-limiting areas and also to estimate yield gaps for major soybean regions of India (Table 3) [17].

\subsection{DSS in crop water requirements management}

DSS is also applied to careful management of water resources, crop water requirements. Crop water requirements depend on the factors such as evaporation, evapotranspiration, meteorological factors such as solar radiation, air temperature, humidity, wind speed etc. [18].

CROPWAT DSS helped to decide irrigation scheduling for different crop patterns and to calculate crop water requirements in eastern Godavari Delta, Andra Pradesh [19] [20]. Along with climatic data it helped in assessment of reference evapotranspiration under temperature conditions of Kashmir Valley [21]. It also gave good results when applied to simulate different crop water requirements as per the need of crop under different planting dates and probable canal water supplies for Noorpur distributary of Western Yamuna Canal system, West Bengal (Table 3) [22]. Along with the 
GIS mapping model it was used to spatially analyze and study crop water requirements of rice in the eastern part of India. It also helped to study the spatial variation of climatic water balance, probabilistic monthly monsoon rainfall and mapping of cold periods in the region [23].

\subsection{DSS in irrigation scheduling}

Irrigation scheduling is one of the important activities in agriculture. A DSS tool for Simulation of WAter and SALT (SWASALT) was calibrated and validated for irrigated areas in the semi - arid region of Haryana. It helped to prevent on farm water logging and soil salinization because of canal irrigation [24] [25]. This model was also used to calculate Water Management Response Indicators (WMRI) which helped to optimize the on farm irrigation schedule by minimizing the percolation losses to ground water for different soil types (Table 3) [24] [26].

GIS based integrated model of rainfall, soil, water use, canal flow model, soil water balance model and groundwater flow model is used as an effective DSS tool. It helped to increase crop production for different cropping pattern as per the groundwater availability for Godavari Delta Central Canal Irrigation Project in Andra Pradesh [27].

\subsection{DSS based on climatic data}

Climatic parameters such as temperature, rainfall, sunshine hours play a very important role in crop production. DSSATCropping System Model (DSSAT-CSM) was also applied to study impact of climatic parameters in rice-wheat system productivity over the Indo-Gangetic plains of India. The comparison of observed and simulated rice and wheat yield showed that, along with climatic parameters crop productivity can be improved by integrating biotechnological advancements and precision farming (Table 3) [28].

A simulation based multi-year, multi-crop and daily time step cropping based model called as "Crop Production and Management (CROPMAN)" model was used in Punjab to study the effects of different dates of transplanting and weather parameters on yield, evapotranspiration and water productivity. The analysis showed that rice yield in Punjab can be increased by shifting of transplanting from mid May to lower June onwards (Table 3) [29]. It was also simulated to study grain yield of cheakpea crop for semi-texture soil of Punjab for rice-cheakpea cropping pattern. It was observed that grain yield is increased with rice-cheakpea cropping pattern than rice-wheat pattern. It also successfully concluded that irrigation water requirement is more in the environments of low rainfall and coarse-textured soils compared to mediumtextured soil and high rainfall areas [30].

Evapotranspiration is a basic component hydrological cycle and plays a significant role in crop yield, ground water recharge and land use planning. The DSS-ET, decision support system was designed using climatic data of different ecosystems in India for estimation of evapotranspiration. The DSS was helpful as a research and teaching tool and intermediate parameter estimation and for missing data estimation [31] [32].

\subsection{DSS in advisory system}

Advisory DSS is playing extremely important role in Indian agriculture. e-Sagu, farm specific DSS developed by IIIT, Hyderabad, and Media Lab Asia under the aegis of Media Lab Asia which helped to improve farm productivity by delivering high-quality farm specific agro-expert decisions in a timely manner to each farm at the farmer's doorsteps. The advice was provided at all stages of cultivation of crops from sowing to harvesting, which reduces the cost of cultivation and increases farm productivity as well as quality of Agricultural commodities (Table 3) [33]. "mKRISHITM" DSS tool developed by Tata Consultancy Services and was deployed in Borgaon village, Maharashtra, for proper nutrient and pest management advice for grape farms through mobile phones(Table 3) [34]. Integrated Pest Management is an important parameter in agriculture. An Integrated Pest Management (IPM) DSS called as "Cell Phone" was developed for sustainable plant protection of south 24 paraganas, West Bengal. The DSS helped for sustainable IPM by creating continuous awareness among farmers and in turn to improve crop productivity (Table 3) [35].

\section{CONCLUSION}

It is observed that in India, simulation based techniques are widely applied in different areas of agriculture such as to increase crop yield, crop water requirements, on farm irrigation scheduling, and to study the impact of climatic parameters. Information Communication Technology based advisory systems are also playing an important role in Indian scenario. In India majority of the rural population lives in rain-fed regions, therefore challenge before Indian agriculture is to transform rain-fed farming into more sustainable and productive systems to better support the population dependent on it. The soil nutrient parameters such as Nitrogen $(\mathrm{N})$, Phosphorous and Potassium (K), the other parameters such as soil water content, evapotranspiration, evaporation, soil water restoration index and soil minerals play important role in crop productivity. There is a need to develop a DSS for effective management and utilization of soil nutrients. The literature also shows that there is a need to develop a GIS based decision support systems in India. The expert systems based on spatial database on agriculture will improve the performance on agriculture management which in turn will be helpful for sustainable agriculture management in India. 
Table 3 Comparison of Results of different DSS in Indian Context

\begin{tabular}{|c|c|c|c|c|c|}
\hline Sr.No & Name of DSS & $\begin{array}{l}\text { Parameters } \\
\text { Considered }\end{array}$ & Region in India & $\begin{array}{l}\text { Scenario before implementation } \\
\text { of DSS }\end{array}$ & $\begin{array}{l}\text { Results after } \\
\text { implementation of DSS }\end{array}$ \\
\hline 1. & $\begin{array}{l}\text { DSSAT - } \\
\text { CERES (Wheat) }\end{array}$ & $\begin{array}{l}\text { Climate, Water and } \\
\text { Different Nitrogen } \\
\text { Levels }\end{array}$ & $\begin{array}{l}\text { Semiarid and } \\
\text { Sub Tropical } \\
\text { region of Punjab }\end{array}$ & $\begin{array}{l}\text { Crop productivity was affected due } \\
\text { to increase in depth of quality } \\
\text { ground water. }\end{array}$ & $\begin{array}{l}\text { Improved water productivity } \\
\text { under dry land and limited } \\
\text { water environments. }\end{array}$ \\
\hline 2. & $\begin{array}{l}\text { DSSAT-CSM- } \\
\text { CERES (Wheat) } \\
4.0\end{array}$ & Climatic Data & $\begin{array}{l}\text { Ludhiana and } \\
\text { Phillaur, Punjab }\end{array}$ & \multicolumn{2}{|c|}{$\begin{array}{l}\text { The model was evaluated for } 13 \text { datasets and assisted to increase } \\
\text { crop yield, CWP, IWP. }\end{array}$} \\
\hline 3. & CropSyst & $\begin{array}{l}\text { Deep alluvial loamy } \\
\text { sand typic } \\
\text { Ustripsamment soils } \\
\text { under hyper-thermic } \\
\text { regime }\end{array}$ & $\begin{array}{l}\text { Ludhiana } \\
\text { Punjab }\end{array}$ & $\begin{array}{l}\text { Earlier the transplanting dates of } \\
\text { crops were in May which required } \\
\text { frequent irrigation, to meet the crop } \\
\text { requirement. }\end{array}$ & $\begin{array}{l}\text { Calibrated the model for } \\
\text { shifting of transplanting dates } \\
\text { of rice from May to June, } \\
\text { which helped to increase the } \\
\text { effective water utilization and } \\
\text { in turn improved grain yield. }\end{array}$ \\
\hline 4. & $\begin{array}{l}\text { CROPGRO- } \\
\text { Soybean Model }\end{array}$ & Climatic Data & $\begin{array}{l}\text { Madhya } \\
\text { Pradesh, } \\
\text { Maharashtra, } \\
\text { Rajasthan and } \\
\text { Karnataka }\end{array}$ & $\begin{array}{l}\text { Soybean grain yield was affected by } \\
\text { temporal variations of rainfall. }\end{array}$ & $\begin{array}{l}\text { Calibrated model helped to } \\
\text { increase soybean yield in } \\
\text { water limiting environment } \\
\text { based on climatic data. }\end{array}$ \\
\hline 5 & CROPWAT & $\begin{array}{l}\text { Climatic and crop } \\
\text { data }\end{array}$ & $\begin{array}{l}\text { Andra Pradesh, } \\
\text { Kashmir, West } \\
\text { Bengal }\end{array}$ & $\begin{array}{l}\text { Conventional irrigation scheduling } \\
\text { was affecting crop water } \\
\text { requirements and thus crop yield. }\end{array}$ & $\begin{array}{l}\text { Helped to estimate crop water } \\
\text { requirements to improve } \\
\text { irrigation scheduling and in } \\
\text { turn to increase a crop yield. }\end{array}$ \\
\hline 6. & SWASALT & $\begin{array}{l}\text { Soil and irrigation } \\
\text { data }\end{array}$ & Haryana & $\begin{array}{l}\text { Canal irrigation increased the } \\
\text { percolation losses which resulted } \\
\text { water logging and soil salinization. }\end{array}$ & $\begin{array}{l}\text { Prevented Water logging and } \\
\text { soil salinization which helped } \\
\text { for effective utilization of } \\
\text { water resources. }\end{array}$ \\
\hline 7. & DSSAT-CSM & Climatic Data & Punjab & $\begin{array}{l}\text { Only climatic parameters were } \\
\text { considered for crop productivity } \\
\text { improvement. }\end{array}$ & $\begin{array}{l}\text { Model results indicated that } \\
\text { there is a need integrate } \\
\text { biotechnological techniques } \\
\text { and precision farming. }\end{array}$ \\
\hline 8. & CROPMAN & $\begin{array}{l}\text { Site Specific Climatic } \\
\text { Data }\end{array}$ & Punjab & $\begin{array}{l}\text { Crop productivity was affected by } \\
\text { incorrect transplanting dates which } \\
\text { increased soil evapotranspiration } \\
\text { and reduced water produced. }\end{array}$ & $\begin{array}{l}\text { A yield can be increased by } \\
\text { shifting of transplanting from } \\
\text { mid May to lower June } \\
\text { onward }\end{array}$ \\
\hline 9. & e-Sagu & $\begin{array}{l}\text { Climatic Data, Farm } \\
\text { specific crop details }\end{array}$ & Tamilnadu & $\begin{array}{l}\text { There was a need to provide the } \\
\text { farm specific pest management and } \\
\text { other advice. }\end{array}$ & $\begin{array}{l}\text { Helped farmers for farm } \\
\text { specific agro-expert decisions } \\
\text { to the farmers to increase the } \\
\text { crop yield. }\end{array}$ \\
\hline 10. & mKRISHITM & $\begin{array}{l}\text { Climatic Data, Farm } \\
\text { specific crop details }\end{array}$ & Maharashtra & $\begin{array}{l}\text { There was a need to bridge the gap } \\
\text { between farmers and agriculture } \\
\text { expert for proper nutrient and pest } \\
\text { management. }\end{array}$ & $\begin{array}{l}\text { Helped farmers for nutrient } \\
\text { and pest management for } \\
\text { Grape farms. }\end{array}$ \\
\hline 11. & IPM & $\begin{array}{l}\text { Climatic Data, Farm } \\
\text { specific crop details }\end{array}$ & West Bengal & $\begin{array}{l}\text { No support for effective Pest } \\
\text { Management for crops. }\end{array}$ & $\begin{array}{l}\text { Assisted farmers increase } \\
\text { awareness about pest } \\
\text { management. }\end{array}$ \\
\hline
\end{tabular}




\section{REFERENCES}

[1] Anonymous (2011) Annual Report 2010-2011 Department of Agriculture and Cooperation , Ministry of Agriculture, Government of India, March, 2011.

[2] G.Kaur (2009),"Socio-economic status of farmers during pre and post liberalization:A case study from Punjab" ,M.Phil, Dissertation School of management and social sciences Thapar university, Patiala ,India.

[3] M. Narayana Reddy and N.H.Rao "GIS Based Decision Support Systems in Agriculture", National Academy of

Agricultural Research Management Rajendranagar, 1995, pp. 1-11.

[4] P. Heinemann, "Decision Support Systems for Food and Agriculture", Systems Analysis and Modeling in Food and Agriculture, Encyclopedia of Life Support Systems (EOLSS).

[5] J.D Cain, K Jinapala, I.W Makin, P.G Somaratna, B.R Ariyaratna, L.R Perera, "Participatory decision support for agricultural management. A case study from Sri Lanka”, Agricultural Systems, Volume 76, Issue 2, May 2003.

[6] J.W. Jones, G.Hoogenboom, C.H Porter, K.J.Boote, W.D.Batchelor, L.A.Hunt, P.W Wilkens, U Singh, A.J.Gijsman,J.T Ritchie, "The DSSAT cropping

System model", European Journal of Agronomy, Volume 18, Issues 3-4, January 2003.

[7] K.R.Thorp, K.C. DeJonge, A.L. Kaleita, W. D. Batchelor, J. O. Paz. "Methodology for the use of DSSAT models for precision agriculture decision

Support". Computers and Electronics in Agriculture, Volume 64, Issue 2, December 2008.

[8] K.A. Dzotsi, J.W. Jones, S.G.K. Adiku, J.B. Naab, U. Singh, C.H. Porter, A.J. Gijsman, "Modeling soil and plant phosphorus within DSSAT", Ecological Modelling, Volume 221, Issue 23, 24 November 2010.

[9] H.L. Liu, J.Y. Yang, C.S. Tan, C.F. Drury, W.D. Reynolds, T.Q. Zhang, Y.L. Bai, J. Jin, P. He, G. Hoogenboom, "Simulating water content, crop yield and nitrate-N loss under free and controlled tile drainage with subsurface irrigation using the DSSAT model", Agricultural Water Management, Volume 98, Issue 6, April 2011.

[10] S.A. Saseendran, L. Ma, R. Malone, P. Heilman, L.R. Ahuja, R.S. Kanwar, D.L. Karlen, G. Hoogenboom, "Simulating management effects on crop production, tile drainage, and water quality using RZWQM-DSSAT", Geoderma, Volume 140, Issue 3, 15 July 2007.

[11] V.K. Arora, H. Singh, B. Singh, "Analyzing wheat productivity responses to climatic, irrigation and fertilizer-nitrogen regimes in a semi-arid sub-tropical environment using the CERES-Wheat model", Agricultural Water Management, Volume 94, Issues 1-3, 16 December 2007, Pages 22-30

[12] J. Timsina, D. Godwin, E. Humphreys, Y.Singh, B.Singh, S. Kukal, D. Smith,"Evaluation of options for increasing yield and water productivity of wheat in Punjab, India using the DSSAT-CSM-CERES-Wheat model", Agricultural Water Management, Volume 95, Issue 9, September 2008.

[13] S.K. Jalota, K.B. Singh, G.B.S. Chahal, R.K. Gupta, S. Chakraborty, A.Sood, S.S. Ray, S. Panigrahy, "Integrated effect of transplanting date, cultivar and irrigation on yield, water saving and water productivity of rice (Oryza sativa L.) in Indian Punjab: Field and simulation study", Agricultural Water Management, Volume 96, Issue 7, July 2009.

[14] A. K. Singh, R. Tripathy, U. K. Chopra, "Evaluation of CERES-Wheat and CropSyst models for water-nitrogen interactions in wheat crop", Agricultural Water Management, Volume 95, Issue 7, July 2008.

[15] M Lal, K.K Singh, G Srinivasan, L.S Rathore, D Naidu, C.N Tripathi, "Growth and yield responses of soybean in Madhya Pradesh, India to climate variability and change" , Agricultural and Forest Meteorology, Volume 93, Issue 1, 25 January 1999.

[16] R.K Mall, M Lal, V.S Bhatia, L.S Rathore, R. Singh, "Mitigating climate change impact on soybean productivity in India: a simulation study", Agricultural and Forest Meteorology, Volume 121, Issues 1-2, 20 January 2004

[17] V.S. Bhatia, P. Singh, S.P. Wani, G.S. Chauhan, A.V.R. Kesava Rao, A.K. Mishra, K. Srinivas, "Analysis of potential yields and yield gaps of rain-fed soybean in India using CROPGRO-Soybean model", Agricultural and Forest Meteorology, Volume 148, Issues 8-9, 4 July 2008 .

[18] R.G. Allen, L.S. Pereira, D. Raes, M. Smith, "Crop evapotranspiration - Guidelines for computing crop water requirements - FAO Irrigation and drainage paper 56", FAO - Food and Agriculture Organization of the United Nations, Rome, 1998

[19] G. Stancalie, A. Marica, L. Toulios, "Using earth observation data and CROPWAT model to estimate the actual crop evapotranspiration", Physics and Chemistry of the Earth, Parts A/B/C, Volume 35, Issues 1-2, 2010

[20] Anonymous (1997), "Development of Data Simulation Model and Irrigation Schedules for Eastern Godavari Delta, Andra Pradesh", National Institute of Hydrology, Roorkee, India

[21] W. Raja, "Validation of CROPWAT 8.0 for Estimation of Reference Evapotranspiration using Limited Climatic Data under Temperate Conditions of Kashmir", Research Journal of Agricultural Sciences 2010.

[22] T.B.S. Rajput, N. Patel "Determination of the Optimal Date for Sowing of Wheat in Canal Irrigated Areas using FAO CROPWAT Model", Water Technology Centre, IARI, New Delhi, India.

[23] G.Kar, H.N. Verma, "Climatic water balance, probable rainfall, rice crop water requirements and cold periods in AER 12.0 in India", Agricultural Water Management, Volume 72, Issue 1, 2 March 2005

[24] R. Singh, J. Singh, "Irrigation planning in wheat (Triticum aestivum) under deep water table conditions through simulation modeling", Agricultural Water Management, Volume 33, Issue 1, May 1997. 
[25] A. Singh, "Decision support for on-farm water management and long-term agricultural sustainability in a semi-arid region of India", Journal of Hydrology, Volume 391, Issues 1-2, 14 September 2010.

[26] R.Singh,J.Singh, "Irrigation planning in cotton through simulation modeling", Irrigation Science, Volume 17,Issue 1,November 1996.

[27] V.M Chowdary, N.H Rao, P.B.S Sarma. "GIS-based decision support system for groundwater assessment in large irrigation project areas". Agricultural Water Management, Volume 62, Issue 3, 30 October 2003.

[28] N. Subash, H.S. Ram Mohan, " Evaluation of the impact of climatic trends and variability in rice-wheat system productivity using Cropping System Model DSSAT over the Indo-Gangetic Plains of India", Agricultural and Forest Meteorology, Volume 164, 15 October 2012.

[29] G.B.S. Chahal, A. Sood, S.K. Jalota, B.U.Choudhury,P.K. Sharma, "Yield, evapotranspiration and water productivity of rice (Oryza sativa L.)-Wheat (Triticum aestivum L.) system in Punjab (India) as influenced by transplanting date of rice and weather parameters", Agricultural Water Management, Volume 88, Issues 1-3, 16 March 2007.

[30] S.K. Jalota, A. Sood, W.L. Harman, "Assessing the response of chickpea (Cicer aeritinum L.) yield to irrigation water on two soils in Punjab (India): A simulation analysis using the CROPMAN model", Agricultural Water Management, Volume 79, Issue 3, 10 February 2006.

[31] A. Bandyopadhyay, A. Bhadra, R.K. Swarnakar, N.S. Raghuwanshi, R. Singh, "Estimation of reference evapotranspiration using a user-friendly decision support system: DSS_ET", Agricultural and Forest Meteorology, Volumes 154-155, 15 March 2012.

[32] B. George , B. Reddy, N. Raghuwanshi, W. Wallender "Decision Support System for estimating Reference Evapotranspiration", Journal of Irrigation and Engineering, 2002 128:1, 1-10

[33] P. Reddy, G. Ramaraju. "e-Sagu: The Next Generation IT-based Query-less, Cost-Effective and Personalized Agro-Advisory System" Media Lab Asia Project, IIIT, Hyderabad.

[34] A. Pande et al, "m-KRISHI Market Facing Innovation", TATA Consultancy Services TCS Innovation Lab, Mumbai

[35] L.Patel,Mondal C,Maitra N," Cell Phone - A Decision Support for sustainable plant protection of the district South 24 Parganas, West Bengal", Global Jounal of BioScience \& Bio-Technology, 2012, Volume .1 (1) 2012 59-64 